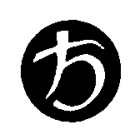

\title{
TUSCULUM-BUCHEREI
}

Herausgeber: Karl Bayer, Max Faltner, Gerhard Jäger 



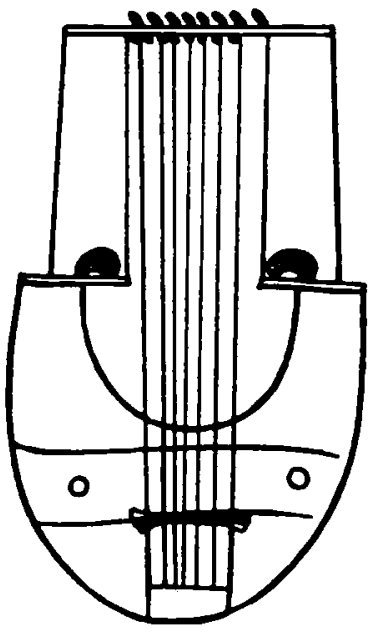

ALKAIOS

Griechisch und deutsch

herausgegeben von Max Treu 


\section{Auflage 1980}

(c) Heimeran Verlag, München 1952

Alle Rechte vorbehalten, einschlieBlich

die der fotomechanischen Wiedergabe

Satz und Druck: Laupp \& Göbel, Tübingen

Bindung: Heinr. Koch, Tübingen

Archiv 192 ISBN 3-7765-2002-7 